\title{
OBSADA BISKUPSTWA TARNOWSKIEGO W LATACH 1783-1807
}

Jest to trzeci $\mathrm{z}$ rzędu artykuł poświęcony obsadzie biskupstw obrządku łacińskiego w Galicji. Poprzednie dwa ukazały się również na łamach Analecta Cracoviensia: pierwszy z nich dotyczył obsady biskupstwa krakowskiego w okresie niewoli narodowej ${ }^{1}$, drugi zaś był poświęcony obsadzie łacińskiej metropolii we Lwowie w tym samym okresie, czyli od pierwszego rozbioru Polski (1772) do odzyskania niepodległości w r. $1918^{2}$. Podstawę źródłową tych prac stanowią obfite archiwalia wiedeńskie i watykańskie, z których miałem możność wybrać potrzebną dokumentację.

Pierwszą diecezją, ufundowaną przez rząd zaborczy na ziemiach zabranych Polsce, było arcybiskupstwo mohylowskie. Fundatorką tej archidiecezji ze stolicą w Mohylewie nad Dnieprem była carowa Katarzyna II. Odpowiedni ukaz carycy nosi datę 28 stycznia 1782 roku. Erekcji dokonał papież Pius VI na mocy bulli Onerosa pastoralis officii (15 IV 1783) ${ }^{3}$.

Diecezja tarnowska, jako druga $\mathrm{z}$ kolei, powstała w podobnych okolicznościach. Została ona uformowana dla tych ziem diecezji krakowskiej, które na skutek pierwszego rozbioru Polski znalazły się pod panowaniem Austrii. Było tu około 400 parafii i placówek duszpasterskich oraz 1139436 wiernych. Starania Austrii o wyłączenie tych ziem z diecezji krakowskiej i utworzenie dla nich nowego biskupstwa w Tarnowie rozpoczęły się w roku 1773 i trwały 14 lat (1786). Główne etapy formowania tej diecezji to: (1) utworzenie przez biskupa krakowskiego Ignacego Kajetana Sołtyka odrębnego dla tych ziem wikariatu i ofi-

1 B. Kumor, Obsada biskupstwa krakowskiego w latach 1790-1914. „Analecta Cracoviensia" 8 (1976) $321-343$.

2 B. Kumor, Obsada metropolii lwowskiej obrzadku tacińskiego w latach 1772 1918. „Analecta Cracoviensia” 9 (1977) 447-469. $179 \mathrm{n}$.

B. Kumor, Granice metropolii $i$ diecezji polskich 968-1939, ABMK 1969-1971, 
cjalatu generalnego w Zakrzówku koło Krakowa (27 IX 1777), (2) przeniesienie jego siedziby do Tarnowa (26 II 1781), (3) samowolne utworzenie diecezji przez cesarza Józefa II (20 IX 1783), (4) porozumienie w tej sprawie między Wiedniem i Krakowem (4 VII 1785), (5) erekcja diecezji dokonana przez papieża Piusa VI bullą In suprema beati Petri z dnia 13 III $1786 \mathrm{r}^{4}$

A jak wyglądała sprawa obsady nowoutworzonego biskupstwa? Radca Nadwornej Kancelarii Cesarskiej w Wiedniu F. J. Heinke w memoriale z października 1787 r., złożonym na ręce cesarza Józefa II, postawił tezę, że cesarz może nawet bez zgody Stolicy Apostolskiej mianować metropolitów i biskupów i przekazywać im temporalia i spiritualia (dobra i jurysdykcję kościelną) w zarząd kościelny $\mathrm{w}$ diecezji ${ }^{5}$. Taką też postawę przyjęli cesarze austriaccy. Opór Stolicy Apostolskiej łamano faktami dokonanymi, jak to miało miejsce w wypadku obsady metropolii w Lublianie (1787) ${ }^{6}$. Tak było również w Galicji. Do r. 1772 biskupstwa ob. łac. we Lwowie i Przemyślu obsadzal faktycznie król polski, ale zaborcze władze austriackie już 22 lutego 1777 r. postanowiły, „że w sprawach kościelnych należy wykonywać wszystkie prawa króla apostolskiego we wszystkich przypadkach jak na Węgrzech". Oznaczało to, że Maria Teresa i jej następcy mają pełne prawo prezenty i patronatu $\mathrm{w}$ stosunku do biskupstw galicyjskich. W oparciu o te prawa cesarzowa Maria Teresa zamianowała (17 I 1778) ks. Ferdynanda Kickiego koadiutorem $\mathrm{z}$ prawem następstwa we Lwowie, po śmierci metropolity W. H. Sierakowskiego (25 X 1780) objął on rządy jako ordynariusz lwowski. W następnym roku w podobny sposób, poprzez koadiutorię $\mathrm{z}$ prawem następstwa zostało obsadzone biskupstwo obrządku łacińskiego w Przemyślu w osobie ks. Antoniego Wacława Betańskiego, który w styczniu 1783 r. po śmierci J. T. Kierskiego przejął rządy w diecezji jako ordynariusz ${ }^{7}$.

Diecezja tarnowska została formalnie erygowana w r. 1786, ale sprawa jej obsady była rozważana już od r. 1777, tj. od czasu utworzenia odrębnego wikariatu i oficjalatu generalnego dla galicyjskiej części diecezji krakowskiej. Oczywiście i tym razem władze austriackie nie czekały na przyznanie im praw patronackich przez Stolicę Apostolską, ale postępowały tak, jak gdyby je posiadały, choć przecież otrzymały je

4 B. Kumor, Dzieje polityczno-geograficzne diecezji tarnowskiej, Lublin 1958, 23-28; tenże, Granice, 220-222.

5 F. Maass, Der Josephinismus. Quellen zu'seiner Geschichte in Österreich 1760-1790. Bd $3 \mathrm{nr}$ 11, 402-421 (październik 1787), $\mathrm{nr} 12,422-444$ (koniec 1787 r.).

B B. Kumor, Obsada metropolii lwowskiej, 448, 451.

7 S. Łempicki, Betański Antoni Wackaw, [w:] PSB I, 475-477; W. Chotkowski, Historia polityczna Kościoła w Galicji za rzqdów Marii Teresy, t. 1, Kraków 1909, 423-433. 
formalnie dopiero w r. 1785. Ponieważ biskupstwo w Tarnowie nie było utworzone, a diecezją krakowską zarządzał faktycznie biskup I. K. Sołtyk, dlatego na wypadek jego choroby władze austriackie wszczęły starania w Rzymie o nominację dla Tarnowa wikariusza apostolskiego z sakrą biskupią. Taki wniosek złożył 13 lipca 1774 r. hr. E. Wbrna, kierownik Nadwornej Kancelarii Galicyjskiej w Wiedniu, na ręce kanclerza cesarstwa ks. W. A. Kaunitza, który poparł ten wniosek (18 VII 1774). W Wiedniu postanowiono jednak, że „chociaź na przyszłość powinni biskupi być wybierani z kleru "galicyjskiego", to jednak na pierwszy raz należało wybrać kandydata z krajów austriackich. Ponieważ 30 czerwca 1774 r. gubernator Galicji hr. H. Auersperg doniósł do Wiednia wiadomość o psychicznej chorobie biskupa Sołtyka, dlatego już 23 lipca t.r. referent spraw duchownych w Wiedniu Evers przedłożył cesarzowej Marii Teresie kandydaturę biskupa z St. Pölten w Austrii Henryka Jana Kerensa na wikariusza apostolskiego do Tarnowa ${ }^{8}$. Kandydat, były jezuita, był w latach 1769-1775 biskupem w Roermond w Holandii, a od 22 grudnia 1773 r. administratorem apostolskim diecezji Wiener Neustadt w Austrii ${ }^{9}$.

Ale ten zniemczony Belg, mimo iż wyraził ,gotowość objęcia tymczasowego stanowiska w Galicji", nie miał piastować żadnego urzędu kościelnego na ziemiach polskich. W dniu 6 XI 1973 r. został mianowany przez cesarzową biskupem w Wiener Neustadt, a prekonizację papieską otrzymał dopiero 3 IV 1775 r. Zmarł (26 XI 1792) na stanowisku biskupa w St. Pölten w Austrii Dolnej ${ }^{10}$.

Cesarzowa nie zaakceptowała kandydatury biskupa Kerensa, ale wyraziła życzenie, by na wikariat apostolski w Tarnowie, „wybrać dzielne subiectum z kleru czeskiego i morawskiego". W odpowiedzi na to hr. Wbrna $\mathrm{w}$ imieniu kancelarii galicyjskiej zwrócił się (30 VII 1774) do Nadwornej Kancelarii Czesko-Austriackiej o wytypowanie odpowiedniego kadydata, a ta już w dniu następnym wskazała na ks. Macieja Chorinsky'ego. Kim był proponowany kandydat? Miał on wówczas 64 lata życia i był kanonikiem kapituły ołomunieckiej, oraz dziekanem infułatem kapituły kolegiackiej w Brnie Morawskim. Od 11 IX 1769 r. był biskupem tytularnym samarytańskim i pomocniczym w Hradec Kralo-" ve ${ }^{11}$. Mówił dobrze po czesku i w tym języku głosił kazania, stąd sądzono, że „mógłby łatwo porozumieć się z Polakami”, a jego uczoność i rżetelne zasady postępowania uprawniały do przypuszczenia, że „Naj-

${ }^{8}$ W. Chotkowski, jw., t.: 2, 25-58; Hierarchia catholica, t. 6 (1730-1799), 306. Wspomniany ks. Chotkowski informuje błędnie, że kandydatem tym był ks. Franciszek Berchtold, który jako biskup został przeniesiony $\mathrm{z}$ Wiener Neustadt do St. Pölten. Takiego biskupa ani w Wiener Neustadt, ani w St. Pölten nie było.

9-10 Hierarchia catholica, t. 6, 306, 361.

11 Tamże, 365 . 
jaśniejsza Pani mogłaby się z jego nominacji spodziewać pomyślnych skutków".

Tę też kandydaturę zaaprobowała Nadworna Kancelaria Galicyjska (3 VIII t.r.), ale przy tej okazji wysunęła bardzo ciekawe postulaty:

$1^{\circ}$ Biskup Chorinsky winien tylko ad interim przejąc rządy w galicyjskiej części diecezji krakowskiej w charakterze wikariusza apostolskiego tylko w wypadku śmierci biskupa krakowskiego I. K. Sołtyka.

$2^{\circ} \mathrm{W}$ wypadku utworzenia diecezji tarnowskiej biskupem nowej diecezji winien zostać kandydat z kleru galicyjskiego, by „przy pierwszym nadarzającym się wakansie nie zasmucać kleru galicyjskiego".

$3^{\circ} \mathrm{W}$ późniejszym okresie należy przyjąc zasadę, by duchowni galicyjscy byli mianowani biskupami $\mathrm{w}$ dziedzicznych krajach austriackich, zaś duchowni z tychże krajów - w Galicji ${ }^{12}$.

Sprawa, zdaniem Wiednia, musiała być niezwykle paląca, skoro już 7 sierpnia t.r. nominacja cesarzowej dla biskupa Chorinsky'ego została podpisana, ale nominat nie mógł przejąć rządów w Tarnowie, jako że zdrowie biskupa Sołtyka z Krakowa na tyle się polepszyło, iż mógł on przejąc osobiście rządy $\mathrm{w}$ całej diecezji krakowskiej ${ }^{13}$. W tak zmienionej sytuacji biskup Chorinsky otrzymał probostwo w Petrovie koło Brna, a dnia 9 VI 1777 r. Maria Teresa zamianowała go pierwszym biskupem nowoutworzonej diecezji w Brnie na Morawach. Prekonizację papieską otrzymał 15 XII 1777 r., zmarł 30 X 1786 r. $^{14}$

Sprawa wikariusza apostolskiegơ dla galicyjskiej części diecezji krakowskiej odżyła na nowo, kiedy w lutym 1775 r. biskup Sołtyk przybrał koadiutora $\mathrm{w}$ osobie brata króla polskiego M. J. Poniatowskiego ${ }^{15}$. Austria zainteresowana więcej utrwaleniem własnego stanu posiadania w Galicji, niż prawdziwymi potrzebami duszpasterskimi, postanowiła przeciwdziałać i koadiutora Poniatowskiego nie dopuścić do przejęcia rządów kościelnych w Galicji. W takich też okolicznościach doszło do wznowienia planu nominacji wikariusza apostolskiego dla Tarnowa. Nadworna Kancelaria Czesko-Austriacka w osóbie radcy dworskiego Heinke zaproponowała, by na to stanowisko „mógł być wybrany kandydat z kleru galicyjskiego". Ponieważ jednak czas naglił, dlatego zaniechano konsultacji $\mathrm{w}$ tej sprawie $\mathrm{z}$ Gubernium galicyjskim, a Kan-

12 Allgemeines Verwaltungsarchiv. Wien. Alte Kultus Akten. Acta Nr 33 Dioecese Separation. Generalia (Galizien): Wniosek Nadwornej Kancelarii Galicyjskiej 23 VII 1774; Nota Nadwornej Kancelarii Czesko-Austriackiej - 30 VII 1774; Nota hr. Wbrna - 31 VII 1774.

13 Tamże. Nr 16 ex Augusto 1774. Kanclerz Wbrna do ks. Kaunitza - 9 VIII 1774 ; por. W. Chotkowski, jw., t. 2, 30.

14 Hierarchia catholica, t. 6, 133.

15 Archiwum Kurii Metropolitalnej w Krakowie. Acta Episcopalia vol. $100 \mathrm{k}$. 222-225 (19 II 1775). Prekonizacja papieska nastapiła 3 IV 1775 r. - zob. Hierarchia catholica, t. 6, 186. 
celaria wysunęła na to stanowisko zniemczonego archidiakona ołomunieckiego ks. Franciszka Schubirtza. Maria Teresa zaakceptowała tę kandydaturę, o czym powiadomiono guberniatora Galicji hr. Auersperga (28 XII 1776), a 3 lutego 1777 r. zwróciła się ona w osobistym liście do papieża Piusa VI, by „dla tej części diecezji krakowskiej, która jest położona w Królestwie naszym Galicji, raczył tymczasowo ustanowić wikariusza apostolskiego, który by Waszej Swiątobliwości wyłącznie był poddany i podległy, a spełniał $\mathrm{w}$ tejże części diecezji wszelkie obowiązki należące do urzędu biskupa i duchowej jurysdykcji”. Zanim jednak pismo cesarzowej doszło do Rzymu, kandydat na wikariat apostolski w Tarnowie zmarł (przed 8 II 1776) ${ }^{16}$. Tak więc i ta trzecia kandydatura zeszła niepostrzeżenie ze sceny tarnowskiej, żanim się na niej ukazała.

Ale sprawa wyłączenia galicyjskiej części diecezji z biskupstwa krakowskiego i uformowania z niej nowej diecezji była zbyt ważną akcją polityczną dla Austrii, by poniechano dalszych starań w tym zakresie. Toteż 28 lutego 1777 r. Nadworna Kancelaria Czesko-Austriacka wysunęła na stanowisko wikariusza apostolskiego do Tarnowa zniemczonego Czecha ks. Jana Prokopa Schaffgotscha. Z urodzenia był prażaninem i miał wówczas zaledwie 30 lat (ur. 22 V 1748), od 25 V 1771 r. pełnił obowiązki wikariusza generalnego diecezji Hradec Kralowe i dyrektora Seminarium Duchownego w Ołomuncu. Po otrzymaniu pozytywnej opinii od biskupa królodworskiego J. A. von Arco (po 1 HI 1777), Maria Teresa zaaprobowała jego kandydaturę ${ }^{17}$.

Sprawa wydawała się bliska załatwienia, kiedy nieoczekiwanie zainterweniowała Stolica Apostolska za pośrednictwem nuncjusza Józefa Garampiego. W dniu 3 kwietnia $1777 \mathrm{r}$. podczas spotkania z cesarzową wyjaśnił on, że sprawa podziału diecezji krakowskiej i mianowania wikariusza apostolskiego w Tarnowie ,przez wzgląd na biskupów polskich jest bardzo nie miła”, ponieważ przy podziale Polski w r. 1772 „Rzeczpospolita nie mogła w traktacie zgodzić się na podział diecezji, bo nie miała do tego wyraźnego upoważnienia biskupów i kapituł". Zresztą na sejmie tym nie był obecny biskup krakowski Sołtyk. Odnośnie zaś nominacji wikariusza apostolskiego w Tarnowie nuncjusz oświadczył, że ,ten nie może być ustanowiony bez zgody biskupa krakowskiego". Zapytywał też, czy kandydat zna język polski, ,bez czego byłoby zbyt głupio i przeciwne zasadzie powierzać mu kierownictwo tak licznej ludności, która mówi po polsku" ${ }^{18}$.

${ }^{16}$ Hof- Haus- und Staatsarchiw. Wien. Rep. Z: Romana. Fasc. 68. Schreiben an den Papst 1760-1780 k. 211-212; W. Chotkowski, jw., t. 2, 35-38, 504-505 (przedruk listu).

17 Hierarchia catholica, t. 6, 133; por. W. Chotkowski, jw., t. 2, 38-41.

18 Allgemeines Verwaltungsarchiv. Wien. Alte Kultus Akten. Acta 33 Dioecese Separation Generalia. Nr 12 ex Februario 1777. Nota do Kancelarii Czesko-Austriac- 
To łączenie obydwóch spraw i uzależnienie ich od zgody biskupa krakowskiego sprawiło, że i tym razem Tarnów nie otrzymał zniemczonego Czecha jako wikariusza apostolskiego. Wprawdzie biurokracja austriacka, a zwłaszcza gubernator Galicji hr. Auersperg w piśmie do Marii Teresy (14 VII 1777) udowadniał, że „Najjaśniejsza Pani jako królowa apostolska Węgier ma niewątpliwe prawo do mianowania biskupów” i „osobnego koadiutora dla tutejszej węgierskiej części diecezji”, ale niezależnie od takich sugestii sprawa ta mocno się komplikowała ${ }^{19}$. Nie rozwiązywała też problemu sugestia Nadwornej Kancelarii CzeskoAustriackiej (3 VII 177), by dla galicyjskiej części diecezji krakowskiej zamianować drugiego, obok biskupa M. J. Poniatowskiego, koadiutora $\mathrm{w}$ osobie ks. J. P. Schaffgotscha. Nie praktykowany nigdy w Kościele postulat, by dla jednej diecezji mianowano równocześnie dwóch koadiutorów z prawem następstwa, musiał upaść ${ }^{20}$.

Tak więc za panowania cesarzowej Marii Teresy (†1780) Tarnów nie otrzymał osobnego wikariusza z sakrą biskupią. Trzeba jednak stwierdzié, że ostatnie lata jej panowania były decydujące dla przyszłości galicyjskiej części diecezji krakowskiej. Na skutek presji zaborczych władz austriackich biskup Sołtyk dekretem z dnia 27 IX 1777 r. utworzył dla tej części diecezji odrębny wikariat i oficjalat generalny w Zakrzówku pod Krakowem, a na stanowisko wikariusza i oficjała powołał biskupa pomocniczego Franciszka Potkańskiego. Był to więc Polak, a nie Czech czy Niemiec, co już stanowiło poważne osiągnięcie dla Krakowa, a do tego jako biskup dysponował dużą niezależnością od Krakowa, na terenach późniejszej diecezji tarnowskiej. W chwili objęcia rządów w Zakrzówku liczył on 69 lat życia (ur. 4 X 1708), 44 lata kapłaństwa i 24 lata biskupstwa. Z chwilą wywiezienia biskupa Sołtyka do Rosji, on zarządzał diecezją krakowską w charakterze administratora ${ }^{21}$. Jego osoba miała podtrzymywać jedność diecezji, którą zdołał utrzymać jeszcze przez następne 4 lata.

Po objęciu rządów przez cesarza Józefa II (1780) biskup Sołtyk na skutek dalszych presji Gubernium galicyjskiego przeniósł siedzibę wikariatu z Zakrzówka do Tarnowa, a na stanowisko oficjała i wikariusza generalnego powołał ks. Jana Duwalla (26 II 1781) ${ }^{22}$. Warto już tu zapytać, kim był ks. Duwall, skoro w najbliższej przyszłości on miał

kiej - 22 II 1777; Ks. Kaunitz do Biskupa w Hradec Kralove - 1 III 1777; por. W. Chotkowski, jw., t. 2, 39-41.

19 Tamże, 28 ex Junio 1777: Gubernator Auersperg do Kancelarii Czesko-Austriackiej - 14 VII 1777 .

20 Tamże, nr 28 ex Julio 1777: Wniosek Kancelarii Czesko-Austriackiej 3 VII 1777; W. Chotkowski, jw., t. 2, 46-58; B. Kumor, Granice, 287 n.

21 Hierarchia catholica, t. 6, 330; B. Kumor, Granice, 288.

22 B.' Kumor, Granice, 288; J. Rzepa, Konsystorz generalny $w$ Tarnowie (1781-1785), „Nasza Przeszłość” 7 (1958), 145-152. 
być pierwszym biskupem mianowanym dla Tarnowa. Był to kapłan diecezji krakowskiej, który po święceniach kapłańskich (1 IV 1747) i studiach teologicznych $\mathrm{w}$ Krakowie oraz studiach prawniczych w Rzymie otrzymał doktorat obojga praw na Uniwersytecie Krakowskim (19 V 1763). W chwili nominacji na urząd oficjała generalnego miał 61 rok życia i był prepozytem kapituły kolegiackiej w Wojniczu (od 1757) oraz proboszczem w Radłowie (od 1757) ${ }^{23}$.

By zapobiec podziałowi diecezji krakowskiej, do którego dążył z całą stanowczością rząd austriacki, biskup I. K. Sołtyk zaproponował Gubernium lwowskiemu w liście z dnia 22 X 1782 r., że chętnie zgodzi się na nominację ks. J. Duwalla na biskupa pomocniczego dla galicyjskiej części diecezji krakowskiej ${ }^{24}$. Tak oto ks. J. Duwall został po raz pierwszy wysunięty na biskupa $\mathrm{w}$ Tarnowie, choć na razie $\mathrm{w}$ charakterze biskupa pomocniczego. Ale koncepcja biskupa Sołtyka była już nie do przyjęcia dla zaborczych władz austriackich. W dniu 21 XII 1781 r. na polecenie ks. Kaunitza ambasador austriacki w Warszawie powiadomił rząd polski, że w wypadku śmierci biskupa Sołtyka rząd austriacki przystąpi niezwłocznie do separacji galicyjskiej części diecezji krakowskiej i mianowania dla niej własnego biskupa ${ }^{25}$. W 6 tygodni później na skutek choroby psychicznej biskupa Sołtyka i jego odosobnienia (9 II 1782) rządy w Krakowie przejął koadiutor Poniatowski. W tej sytuacji rząd austriacki polecił (5 III 1782) przejąć jurysdykcję kościelną w galicyjskiej części diecezji krạkowskiej biskupowi. przemyskiemu J. T. Kierskiemu , jako najbliższemu” i zarządzać nią na sposób sede vacante i we własnym imieniu delegować jurysdykcję wikariusza generalnego ks. Duwallowi w Tarnowie, co bp. Kierski faktycznie uczynił w liście pasterskim z dnia 13 IV 1782 r. ${ }^{26}$ Nieco później cesarz Józef II polecił ks. Duwallowi spełniać akty jurysdykcji kościelnej w imieniu biskupa Sołtyka, a nie w imieniu jego koadiutora Poniatowskiego ${ }^{27}$.

Kiedy się więc stało jasne, że w najbliższej przyszłości diecezja w Tarnowie będzie utworzona, na liście kandydatów pojawiły się 3 nazwiska. Wszyscy trzej byli Polakami z Galicji:

23 Archivum Secretum Vaticanum. Proces. consist. vol. 187. Processus super statu Ecclesiae Tarnoviensis - - et super qualitatibus R. D. Joannis Duwall - 1785 k. 298-303; J. Szymański, Kapituła kolegiacka $w$ Wojniczu 1465-1786, Lublin $1962,157-163$.

24 Allgemeines Verwaltungsarchiv. Wien. Alte Kultus Akten. Fasc. 144. Tarnow (Tyniec, Kielce) Bisthum. Nr $318 \mathrm{Bp} \mathrm{I}$. Sołtyk do Gubernium galicyjskiego $22 \times 1781$ (kopia).

25 Haus- Hof- und Staatșarchiv. Wien. St. R. nr 78 Protocoll 1782. Bd I nr 971.

26 B. Kumor, jw., $289 \mathrm{n}$.

27 Allgemeines Verwaltungsarehiv. Alte Kultus Akten. Fasc. 144. Tarnow (Tyniec, Kielce) Bisthum. Nr 318: Ks. J. Duwall do Gubernium galicyjskiego 15 XI 1782. 
$1^{\circ} \mathrm{Ks}$. Jan Duvall, zalecony na stanowisko biskupa pomocniczego przez biskupa krakowskiego Sołtyka, a później wysunięty przez władze austriackie na ordynariusza w Tarnowie.

$2^{\circ}$ Ks. Antomi Stanisław Podhajecki, kanomik kapituły metropolitalnej we Lwowie, którego kandydaturę na koadiutora bisksupa Soltyka dla galicyjskiej części diecezji $\mathrm{z}$ prawem następstwwa w Tarnowie wysunęła, Nadworna Kancelaria Cessarskla w Wiedniu ${ }^{28}$.

$3^{\circ} \mathrm{Ks}$. Michał Roman Sierakowski, biskup pomocniczy przemyski, który sam zacźął zabiegać o biskupstwo w Tarnowie.

Zabiegi bpa Sierakowskiego zasługują na specjalną uwagę. Miał on wówczas 34 lata (ur. 10 VIII 1748), pochodził $\mathrm{z}$ drobnej szlachty koło Frysztaku nad Wisłokiem. Wyświęcony 1 XI 1773 r., zdobył doktorat obojga praw w r. 1776, oraz probostwo w Dynowie i kanonię katedralną w Przemyślu. Dnia 28 IX 1778 r. otrzymał prekonizację na biskupa pomocniczego w Przemyślu ${ }^{29}$. Szybką karierę duchowną zawdzięczał niewątpliwie biskupowi J. T. Kierskiemu z Przemyśla.

W kwietniu 1782 r. wyjechał on do Wiednia i osobiście złożył w Nadwornej Kancelarii Czesko-Austriackiej obszerną prośbę w języku łacińskim do cesarza Józefa II. W liście tym prosił o powierzenie mu w zarząd galicyjskiej części diecezji krakowskiej ,,przynajmniej w charakterze sufragana i adminištratora". Pisał, że ta olbrzymia część diecezji nie ma dotąd biskupa, stąd on za zgodą biskupa Sołtyka konsekrował tu 4 kościoły i udzielił sakramentu bierzmowania 25 tys. osób. Dodawał też, że ma bardzo szczupłe uposażenie (tylko 1500 flor.), a jego stosunkowo młody wiek stawia go przed biskupem J. T. Kierskim (80 lat) i jego koadiutorem Betańskim (70 lat). Prosił też, by w razie utworzenia biskupstwa w Tarnowie, jemu oddać to biskupstwo. W ciągu 6 miesięcy biskup Sierākowski złożył aż 4 tego rodzaju prośby; trzy z nich nie są datowane, a ostatnia nosi datę 3 IX 1782 r. ${ }^{30}$

Zabiegi biskupa Sierakowskiego o Tarnów pokrzyżowało Gubernium galicyjskie. W liście z 23 VIII 1782 r. gubernator H. Auersperg wypowiedział się przeciwko kandydaturze Sierakowskiego, a na tymczasowego administratora $\mathrm{w}$ Tarnowie wysunął biskupa koadiutora przemyskiego A. W.-Betańskiego. Argumentował zaś w ten sposób, że biskup Sierakowski mieszka w Przemyślu, skąd jest aż 18 mil do Tarnowa, podczas gdy biskup Betański rezyduje w Tyczynie, skąd do Tarnowa

28 B. Kumor, Granice, 289.

${ }^{29}$ Hierarchia catholica, t. $6,348 \mathrm{n}$.

30 Allgemeines Verwaltungsarchiv. Wien. Alte Kultus Akten. Fasc. 144. Tarnow (Tyniec, Kielce) Bisthum. Nr 279 ex Octobri 1782. Bp Sierakowski do ces. Józefa II - koniec kwietnia 1782. Dwie inme prośby bez daty, oraz Bp Sierakowski do ces. Józefa II - 3 IX 1782. 
jest tylko $9 \mathrm{mil}^{31}$. Wydaje się jednak, że nie odległość grała główną rolę w doborze kandydatów na Tarnów, ale ich pochodzenie narodowe. Biskup Sierakowski był Polakiem, zaś biskup Betański - Czechem.

Prośba biskupa Sierakowskiego, jak też i sugestie Gubernium galicyjskiego stały się przedmiotem obrad Nadwornej Komisji Duchownej, która w dniu 23 IX 1782 r. przedstawiła wniosek cesarzowi Józefowi II i zaleciła na stanowisko administratora i sufragana w Tarnowie biskupa Sierakowskiego. Jednakże decyzja cesarza Józefa II była zupełnie inna. Odrzucił on zarówno kandydaturę biskupa Sierakowskiego, jak też biskupa Betańskiego, a na administratora galicyjskiej części diecezji krakowskiej powołał jej dotychczasowego wikariusza generalnego ks. Jana Duwalla, wyznaczając mu uposażenie roczne w wysokości 2000 florenów. Równocześnie, powołując się na przywileje przysługujące apostolskim królom Węgier, zapowiedział jego nominację na biskupa tytularnego $\mathrm{i}$ wszczęcie w Rzymie odpowiednich kroków o jego prekonizację $^{32}$.

W dniu 7 X 1782 r. Nadworna Kancelaria Cesarska wygotowała odpowiednie pismo do Rzymu i przedłożyła je cesarzowi do akceptacji. Zalecono też ks. J. Duwallowi (15 XI 1782), by za pośrednictwem Gubernium galicyjskiego zwrócił się sam do Rzymu w tej sprawie do Franciszka Brunatti, agenta cesarskiego, i kard. Franciszka Herzana posła cesarskiego w Rzymie, co też faktycznie uczynił. List taki w języku łacińskim przygotował ks. J. Duwall i 6 XII 1782 r. za pośrednictwem Gubernium galicyjskiego przesłał go na ręce F. Brunatti. W liście tym ks. Duwall pisał, że galicyjska część diecezji krakowskiej obejmuje 400 kościołów parafialnych, 4 kolegiaty, przeszło 300 beneficjów prostych, 30 klasztorów różnych zakonów, 700 księży diecezjalnych i 300 zakonnych. Tą ogromną i ludną częścią diecezji zarządza konsystorz generalny $\mathrm{w}$ Tarnowie, któremu przewodzi on sam jako wikariusz i oficjał generalny biskupa krakowskiego. Tymczasem mimo ogromu ludności, księży i parafii ta część diecezji nie ma biskupa, a jego konieczności nie trzeba udowadniać. Ponieważ sam cesarz upoważnił go do tego, przeto prosi, by ks. Brunatti jako pełnomocnik cesarski wszczął w Rzymie starania o jego prekonizację na biskupa tytularnego i administratora apostolskiego tej części diecezji krakowskiej. Uposażenie jego mają stanowić dochody probostwa radłowskiego i prepozytury wojnickiej, a nad-

31 Tamże. Gubernium galicyjskie do ces. Józefa II - 23 III 1782 (...für Betanski... die Administration der jurium mere episcopalium in den diesseitigen Krakauer Diöces Antheil ad interim bis Euer. Majestät einen ordentlichen Bischofe ernennen gerufen werde).

${ }_{32}$ Tamże. Nr 279 ex Octobri 1782: Wniosek Nadwornej Komisji Duchownej do ces. Józefa II -22 IX 1782 ; Decyzja ees. Józefa. II -23 IX 1782; por. B. Kumor, Granice, 289. 
to 2000 flor. rocznie. Sakry biskupiej może mu udzielić biskup przemyski J. T. Kierski w asyście opatów z Tyńca i Szczyrzyca ${ }^{33}$.

Sprawa nominacji biskupa Duwalla była bardzo uzależniona od stanowiska królewskiego dworu polskiego w. Warszawie, a także od zgody biskupa i kapituły krakowskiej. Dlatego też agent cesarski F. Brunatti radził ks. Duwallowi w liście z dnia 1 I 1783 r., by sprawę jego nominacji wziął $\mathrm{w}$ ręce nuncjusz apostolski w Wiedniu, a także, by sam cesarz zwrócił się w tej sprawie osobiście do Stolicy Apostolskiej. Tę odpowiedź zakomunikował ks. Duwall Gubernium galicyjskiemu (21 I 1783) i załączył odpowiednie dokumenty i zalecenia. Gubernium zaś ze swej strony w liście z dnia 31 I 1783 r. do cesarza poruszyło jeszcze raz tę sprawę ${ }^{34}$. Wynikiem tych zabiegów był wniosek Nadwornej Komisji Duchownej z dnia 4 III 1783 r., skierowany do cesarza Józefa II, w którym postulowano:

$1^{\circ}$ aby dać odpowiednie uposażenie przyszłemu biskupowi tytularnemu w Tarnowie w wysokości 2000 tys. flor.

$2^{\circ}$ aby kzs. J. Duwall był mianowany biskupem tytularnym dla pełnienia funkcji pontyfikalnych w galicyjskiej części diecezji krakowskiej jako „vicarius generalis vel districtualis”.

$3^{\circ}$ aby kard. Fr. Herzan wszczął starania w Rzymie o utworzenie diecezji tarnowskiej.

Do tych postulatów ks. Kaunitz dołączył jeszcze jeden, a mianowicie, by ks. Duwalla zamianować biskupem tytularnym i wikariuszem apostolskim ${ }^{35}$.

Dnia 20 lutego 1783 r. bp M. J. Poniatowski, jako koadiutor, przejął rządy w diecezji krakowskiej. Fakt ten podziałał w. Wiedniu jak iskra elektryczna. Posunięcia mające na celu utworzenie diecezji tarnowskiej posypały się w bardzo szyblkim tempie. W dniu 4 marca 1783 r. cesarz Józef II zdecydował nieodwołalnie utworzenie biskupstwa w Tarnowie, a w trzy dni później (7 III) przekazał załatwienie tej sprawy posłowi austriackiemu przy Watykanie, zaś 23 IV 1783 r. powtórzył zamiar mianowania ks. Duwalla biskupem tytularnym. Dekretem z dnia 20 IX 1783 r. cesarz utworzył samowolnie diecezję tarnowską z obszarów galicyjskiej części diecezji krakowskiej, a jej pierwszym biskupem zamianował ks. Jana Duwalla. Diecezja istniała odtąd nielegalnie, ale

33 Tamże. Nr 279. ex Octobri 1782: Wniosek Nadwornej Kanceliarii - 7 X 1782; Nr 318 ex Martio 1783: Ks. J. Duwall do Fr. Brunatti -6 XII 1782.

34. Tamże. Nr 318 ex Martio 1783: F. Brunatti do ks. J. Duwalla - 1 I 1783 r.; Grubernium galicyjskie do ces. Józefa II - 31 I 1783; Ks. Duwall do Gubernium galicy jskiego - 21 I 1783.

35. Tamże. Nr 318 ex Martio: Wniosek Nadwornej Komisji Duchownej 4 III 1783; Nota ks. Kaunitza - 20 III 1783. 
biskup nominat posiadał ważną jurysdykkcję kościelną jako wilkariusz generalny biskupa krakowskiego ${ }^{36}$.

Jednakże, jak samo utworzenie diecezji było nie kanoniczme, tak i pierwsza nominacja na Tarnów była nielegalna. Dotąd bowiem biskupstwo w Tarnowie nie istniało kanonicznie, a Stolica Apostolska, która jedynie w tym zakresie mogła nadać władcom Austrii odpowiednie przywileje, faktycznie do r. 1783 takich przywilejów im nie przyznała. Stąd podjęte w Rzymie starania o utworzenie diecezji połączono z zabiegami o uzyskanie dla cesarza prawa prezenty i patronatu i wyznaczania kandydatów na nowe biskupstwo w Tarnowie. Zasadnicze w tym zakresie znaczenie miała umowa $w$ sprawie podziału diecezji krakowskiej, zawarta w Warszawie 4 VII 1784 r. między ordynariuszem i kapitułą krakowską a pełnomocnikiem władz austriackich ${ }^{37}$.

Do pertraktacji w Rzymie upoważniono kard. Fr. Herzana i dla niego Nadworna Kancelaria Cesarska w Wiedniu opracowała specjalne Pro memoria (bez daty). Jeden $\mathrm{z}$ punktów Pro memoria polecał, by przyszła bulla erekcyjna diecezji zagwarantowała cesarzowi Austrii prawo mianowania biskupów dla Tarnowa ${ }^{38}$. Toteż zgodnie $\mathrm{z}$ dekretem Kongregacji Konsystorialnej Sanctissimo domino z 18 XI 1785 r., potwierdzającym plan utworzenia diecezji tarnowskiej, przewidywano, że „Ojciec św. zgodził się, by na zawsze zarezerwować Jego Cesarskiej i Apostolskiej Mości i jego następcom prawo nominacji i prezentowania Biskupowi Rzymu odpowiedniego kandydata na nowoutworzone biskupstwo tarnowskie - - w podobny sposób jalk to ma miejsce przy nominacji innych biskupów w Królestwie Galicji i Lodomerii". To postanowienie dekretu Kongregacji Konsystorialnej potwierdził papież jeszcze raz $\mathrm{w}$ bulli erekcyjnej diecezji In beati Petri z dnia 13 III 1786 r. ${ }^{39}$ Tak było rzeczywiście; do $1785 \mathrm{r}$. cesarz obsadzał faktycznie stolicę metropolitalną we Lwowie (1780), jak też biskupstwo w Przemyślu (1783).

Ciekawe jednak, że zanim ukazał się dekret Sanctissimo domino, Rzym faktycznie pogodzil się $\mathrm{z}$ faktem nominacji ks. J. Duwalla na przyszłe biskupstwo w Tarnowie. W dniu 3 XI 1785 r. cesarz Józef II zwrócił się osobiście do papieża Piusa VI z prośbą o prekonizację ks. Duwalla „znanego z zasług, wiedzy i szlachetności życia”, którego on zamianował biskupem tarnowskim * Prośbie cesarza zadośćuczyniono

36 B. Kumor, Granice, $289 \mathrm{n}$.

37 Dziesięć dokumentów związanych $z$ utworzeniem diecezji tarnowskiej, wyd. B. Kumor, ABMK 30 (1975) $\mathrm{nr} 2,353-355$.

${ }_{38}$ Allgemeines Verwaltungsarchiv. Wien. Alte Kultus Akten. Fasc. 144. Tarnow (Tyniec, Kielce) Bisthum. Nr 466 ex Novembri 1785: Pro memoria für den Kais. Königl. Minister in Rom Kardinälen Grafen von Herzan - bez daty.

${ }_{39}$ Dziesięć dokumentów, 360-364 (nr 9); B. Kumor, Dzieje polityczno-geogra. ficzne diecezji tarnowskiej, 111-127.

40 Dziesięć dokumentów, 358-359 ( $\mathrm{nr} 7$ ). 
niezwykle szybko. Już w dniu 5 XI 1785 r. Kongregacja Konsystorialna poleciła nuncjuszowi wiedeńskiemu przeprowadzić proces $\mathrm{w}$ sprawie utworzenia diecezji w Tarnowie i kwalifikacji ks. Duwalla na ordynariusza tejże diecezji ${ }^{41}$.

Ponieważ dotąd wypowiedziano różne sądy o przyszłym biskupie tarnowskim ${ }^{42}$, dlatego warto przypatrzeć się bliżej zeznaniom świadków procesu apostolskiego, który odbył się w Wiedniu przed nuncjuszem w dniu 25 XI 1785 r. Świadkami tymi byli: Konstanty z Wiatrowic, Wiktor z Galicji i Konstanty Raszkowski, poseł polski przy dworze cesarskim. Obydwaj zeznawali, że znają osobiście ks. Duwalla i stwierdzali, że kandydat cieszy się nie tylko rzetelną wiedzą, głęboką pobożnością, czystością obyczajów i przykładnym życiem, ale ,,jest najgodniejszym kandydatem na proponowane biskupstwo, a jego prekonizacja może przynieść jak najlepsze owoce dla Kościoła tarnowskiego" ${ }^{43}$.

Pozostaje pytanie, czy ks. J. Duwall byłby prekonizowany przez Stolicę Apostolską. $\mathrm{Na}$ pytanie to trzeba odpowiedzieć z całą pewnością tak. Sam proces informacyjny był jak najbardziej pozytywny dla niego. W aktach procesu nie wysunięto ani jednego zastrzeżenia pod adresem jego osoby. Pozytywne relacje procesu potwierdza nadto wyznanie wiary, złożone przez niego $30 \times 1785 \mathrm{r}$. wobec opata tynieckiego F. Janowskiego ${ }^{44}$. Warto tu dodać, że takie wýznanie wiary składali ci, którzy mieli być prekonizowani przez papieża na proponowane biskupstwa.

Ks. J. Duwall pragnął tej prekonizacji, chociaż już w połowie sierpnia 1785 r. ,zachorował śmiertelnie i spodziewał się końca swego życia". W dniu 28 X 1785 r. skierowal on osobisty list do cesarza Józefa II z prośbą o protekcję w Rzymie przy prekonizacji. Przy tej okazji pisał, że „ma już 70 lat, jest spracowany i pragnie, by przed śmiercią przyszła konfirmacja papieska". Dodawał też, że nie ma żadnego majątku, ponieważ wszystko, co miał, rozdał ubogim ${ }^{45}$. W odpowiedzi na tę prośbę cesarz Józef II w dniu 3 XII 1785 r. zwrócił się w osobistym liście do papieża Piusa VI o prekonizację ks. Duwalla na biskupstwo tarnowskie ${ }^{46}$. Zanim jednak prośba cesarza mogła być rozpatrzona w Rzymie,

41 Tamże, 359-360 (nr 8).

42 Por. J. Rzepa, jw., 170-177; J. Szymański, Kapituła kolegiacka, 157-161.

43 Pelna dokumentacja procesu informacyjnego ks. Duwalla: Archivum Secretum Vaticanum. Vol. 187. Processus super statu Ecclesiae Tarnoviensis - - et super qualitatibus R. D. Joannis Duwall - - ad episcopatum Tarnoviensem nominati 1785 , k. $288-293$.

44 Tamże, k. $324-325$.

45 Allgemeines Verwaltungsarchiv. Wien. Alte Kultus Akten. Fase. 144 Tarnow (Tyniec, Kielce) Bisthum. Nr 466 ex Novembri 1785: Bp J. Duwall do ces. Józefa II -28 X 1785 .

46 Tamże. Nr 975 ex Novembri 1785: Ces. Józef II do pap. Piusa VI - 3 XII 1785. 
ks. Jan Duwall zmarł (13 XII 1785) ${ }^{47}$. Upragnionej prekonizacji nie doczekał się, jako że bulla erekcyjna diecezji tarnowskiej została podpisana przez Piusa VI dopiero 13 III $1786 \mathrm{r}$. Trudno więc było mianować biskupa dla diecezji tarnowskiej, skoro sama diecezja nie została kanonicznie powołana do życia.

Wobec braku kapituły katedralnej w Tarnowie i ze względu na to, że Kraków faktycznie nie spełniał jurysdykcji w galicyjskiej części diècezji, prepozyt kapituły kolegiackiej w Tarnowie ks. Paweł Rola Lubieniecki zwrócił się (13 XII 1785) do biskupa Gołaszewskiego w Przemyślu o jurysdykcję kościelną ,,jeżeli taką posiada”. Ponieważ ten odpowiedział negatywnie, dlatego metropolita lwowski Ferdynand Kicki dokumentem z dnia 31 XII 1785 r. mianował ks. Lubienieckiego ,administratorem generalnym in spiritualibus diecezji tarnowskiej" ${ }^{48}$.

$\mathrm{Na}$ skutek śmierci nominata tarnowskiego ks. Duwalla trzeba było sporządzić nową listę. kandydatów na to biskupstwo. Zwyczajnie listę taką dla Galicji sporządzało Gubernium we Lwowie, chociaż w szczytowej fazie józefinizmu pośredni wpływ na formowanie takiej listy mieli inni ordynariusze z Galicji. Ostateczną listę kandydatów formowała rada gubernialna i wraz z opiniami i personaliami kandydatów wysyłała do Wiednia. Do r. 1848 sprawami nominacji biskupów zajmowała się Nadworna Komisja Duchowna lub Kancelaria Nadworna. Komisja Duchowna układała ostateczną listę kandydatów i wraz z opinią własną i gubernialną przesyłała ją cesarzowi. Jednego z kandydatów, wymienionego na liście, cesarz mianował biskupem ${ }^{49}$.

A jak przebiegal praces nominacji drugiego z rzędu biskupa dla Tarnowa? Już na wstępie trzeba podkreślić, że różnił się on wydatnie od praktyki zaprowadzonej w Galicji, gdzie główną rolę przy wyznaczaniu kandydatów odgrywało Gubernium galicyjskie. Tym razem rolę taką odegrał sam zmarły nominat, ks. Duwall. To on w dniu 20 VIII 1785 r. ,złożony ciężką chorobą i spodziewając się w każdej chwili śmierci, czuł się bardzo zobowiązany, aby złożyć podziękowanie cesarzowi nie tylko za :tyle wyświadczonych mu dobrodziejstw, ale nade wszystko za ten szczególny zaszczyt, że, został mianowany biskupem tarnowskim" Przesyłajac to podziekowanie do Wiednia za pośfednictwem Gubemium galicyjskiego nominat tarnowski wyznak nadt du na przysiege wiernosci, złożona cesarzowi możności w czasie administrácji diecezją tarnowską, czuje się zobowią-

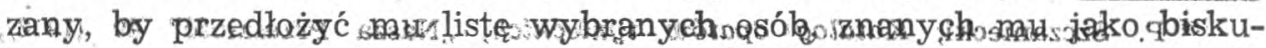

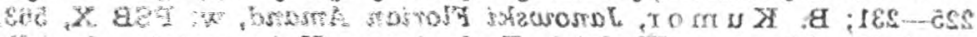

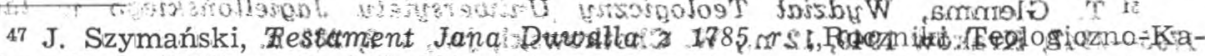

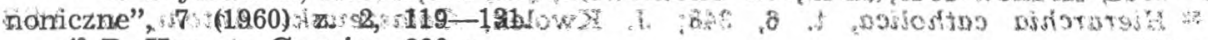

${ }^{48}$ B. Kumor, Granice, $290 \mathrm{n}$.

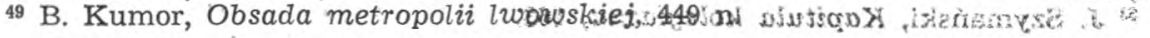


powi z zasług i czystych obyczajów i odpowiedzialności, którzy mogli by przejąć po jego śmierci rządy w diecezji tarnowskiej". Podobnego wypadku nie znamy $w$ dziejach diecezji tarnowskiej, by umierający biskup przedstawiał listę kandydatów na wakującą po sobie stolicę biskupią.

Przypatrzmy się bliżej kandydatom wysuniętym przez ks. Duwalla; oto ich lista $\mathrm{w}$ porządku zaproponowanym w liście do cesarza:

1. Ks. Florian Amand Janowski, opat tyniecki, ,"mąż wielce zasłużony i niezwykłłej prawości". Dodajmy od siebie, że opat Janowski miał wówczas lat 60 (ur. 28 IV 1725), kapłaństwa 36, a opatem w Tyńcu był od r. 1762. Był rzeczywiście człowiekiem światłym, reorganizatorem studium teologicznego i odnowicielem opactwa benedyktyńskiego $\mathrm{w}$ Tyń$\mathrm{cu}$, zniszczonego w czasie wojen z konfederacją barską. Dla Austrii zasłużył się nade wszystko jako pełnomocnik w pertralktacjach o podział diecezji krakowskiej z ordynariuszem i kapitułą krakowską, które doprowadził do pozytywnego rozwiązania; 4 VII $1785 \mathrm{w}$ imieniu władz austriackich podpisał układ, który stanowił podstawę prawną pod erekcję diecezji tarnowskiej ${ }^{50}$.

2. Ks. Jan Franciszek Hoffmann, kanonik kapituły metropolitalnej we Lwowie, zniemczały Czech, generalny wizytator szkół ludowych w Galicji, sprowadzony przez władze austriackie do Lwowa w 1778 r. Był to jeden $\mathrm{z}$ tych Czechów, którzy ,dla chleba i kariery chętnie opuszczali ojczyznę, a jako przybysze znienawidzeni w Galicji, odpłacali się bezwzględnym lekceważeniem jej mieszkańców" ${ }^{51}$.

3. Ks. Antoni Gołaszewski, kanonik kapituły przemyskiej i audytor sądu biskupiego w Przemyślù. Miał wówczas 40 lat, studia teologiczne w Krakowie i zaledwie 6 lat kapłaństwa ${ }^{52}$.

4. Ks. Michał Duwall, kantor kapituły wojnickiej, dziekan jasielski i proboszcz w Szebniach, zasłużony przez 30-letnią pracę duszpasterską. Był on bratem nominata tarnowskiego, mial doktorat $z$ teologii i 60 lat życia ${ }^{53}$.

W dalszej części swego listu do ces. Józefa II biskup Duwall dodawał: „Ponadito kandydatami na biskupstwo w Tarnowie mogą być ci kapłani, których zaproponowałem Wysokiemu Gubernium do gremium .przyszłej kapituły katedralnej w Tarnowie". Dodawał jednak, że z listy tej wyjmuje kandydatów z pierwszego i piątego miejsca, których cho-

50 P. Szczaniecki, Katalog opatów tynieckich, „Nasza Przeszłość" 49 (1978), 225-231; B. K u mor, Janowski Florian Amand, w: PSB X, 563.

$51 \mathrm{~T}$. Glemma, Wydziat Teologiczny Uniwersytetu Jagiellońskiego $w$ latach 1795-1847, Kraków 1949, 12 n.; W. Chotkowski, jw., t. 2, 283 n.

52 Hierarchia catholica, t. 6, 348; J. Kwolek, Gotaszewski Antoni, w: PSB VIII, 237.

53 J. Szymański, Kapituła kolegiacka, 163. 
ciaż „on sam ze względu na pochodzenie szlacheckie, czy też że byli już kanonikami przy kolegiacie, zamieścił ich na liście kanoników katedralnych, a nawet powierzył im urząd sędziego surogata, to jednak obydwaj nie są odpowiednimi na stanowisko biskupa tarnowskiego, jako że nie posiadają odpowiedniego doświadczenia, a nadto jeden $\mathrm{z}$ nich niestety ma wprost brzydką opinię" ${ }^{54}$.

A oto pytanie: jakie kandydatury biskup Duwall wysunął do przyszłej kapituły tarnowiskiej? W Archiwum Diecezjalnym w Tarnowie nie zachowało się żadne pismo w tym zalkresie. Archiwum zaś b. Gubernium galicyjskiego jest ze zrozumiałych względów nie dostępne. Dysponujemy $\mathrm{w}$ tym zakresie wyłącznie odpisami $\mathrm{z}$ tego ostatniego Archiwum w tekach ks. R. Sitki. Otóż zachowany w odpisie list biskupa F. A. Janowskiego do Gubernium galicyjskiego z dnia 1 V 1786 r. informuje, że biskup Duwall złożył w Gubernium we Lwowie odpowiednie projekty; pierwszy przesłał 4 VIII 1785 r., drugi zaś zaledwo na tydzień przed swoją śmiercią - 6 XII 1785 r. Zdaje się, że obydwie propozycje były bardzo zbliżone do siebie. Tę pierwszą bp Janowski musiał mieć pod ręką, skoro w oparciu o nią przyjmował względnie ódrzucał kandydatów do przyszłej kapituły tarnowskiej. Lista jego obejmowała zapewne następujących kandydatów:

1. Ks. Wojciech Mroziński, surogat sądecki i dziekan tamtejszej kapituły kolegiackiej - proponowany na prepozyita kapituły tarnowskiej.

2. Ks. Jan Bochniewicz, dziekan kapituły kolegiackiej w Tarnowie proponowany na dziekana kapituły tarnowskiej.

3: Ks. Michał Duwall, kantor kapituły wojnickiej — proponowaný na kustosza kapituły tarnowskiej.

4-7. Ks. Stanisław Dunin Wąsowicz, ks. Paweł Rola-Lubieniecki, ks. Jan Grabek-Grabowski, ks. Szymon Eodziński ${ }^{55}$.

Można tedy przypuszczać, że ks. Wojciech Mroziński i ks. Paweł Rola Lubieniecki byli wyłączeni $\mathrm{z}$ listy kandydatów na biskupstwo tarnowskie. Trzeba jednak stwierdzić, że tej drugiej listy Gubernium nie przesłało do Wiednia, stąd veto bpa Duwalla w tym zakresie nie miało większego znaczenia.

Projekt obsady biskupstwa tarnowskiego, przesłany 6 XII 1785 r. do Lwowa, Gubernium przesłało do Wiednia jeszcze przed śmiercią biskupa Duwalla, skoro już 14 XII 1785 r., a więc w następny dzień po jego śmierci, Nadworna Komisja Duchowna w Wiedniu rozpatrzyła ten

54 Allgemeines Verwaltlungsarchiv. Wien. Alte Kultus Akten. Fasc. 144 Tarnow (Tyniec, Klielce) Bisthum. Nr 298 ex Aprili 1786: Bp Duwall do Gubernium galicyjskiego - 20 VII 1785; Nr 519 ex Decembri 1785: Bp Duwall do ces. Józefa II 20 VIII 1785.

55 Archiwum Diecezjalne w Tarnowie. Teki ks. R. Sitki: Bp Janowski do Gubernium galicyjskiego - 1 V 1786 . 
projekt i opracowała odpowiedni wniosek w tej sprawie do ces. Józefa II. We wniosku tym, po powtórzeniu nazwisk znanych $\mathrm{z}$ listy bpa Duwalla, Komisja wyraziła opinię, że ,tylko i wyłącznie opat z Tyńca jest jedynym kandydatem, którego nảleży wziąć pod uwagę jako męża znanego i aktywnego, jako tego, który dał najlepsze dowodỳ swej działalności w czasie rokowań o utworzenie diecezji tarnowskiej" ${ }^{56}$.

Ta też kandydatura została przyjęta przez cesarza, który $w$ dniu 23 XII 1785 r. zamianował opata tynieckiego F. A. Janowskiego bisku-

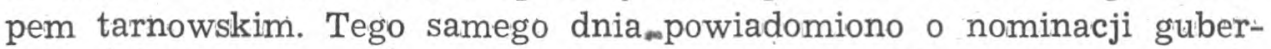
natora Galicji hr. Auersperga we Lwowie ${ }^{57}$. Do Rzymu zwrócono się w sprawie prekonizacji F. A. Janowskiego (26 I 1786), a po dalszej korespondencji, cesarz Józef II w osobistym piśmie do papieża Piusa VI przedstawił swoją prośbę i powiadomił go, że ,na przyszłego biskupa tarnowskiego zamianował Amanda Janowskiego, opata tynieckiego, będąc przekonanym o jego poważnych zasługach, wiedzy, prawości i czystości obyczajów. Proszę przeto, aby Wasza Swiątobliwość raczył go potwierdzić apostolską władzą i instytuować kanonicznie na biskupstwo tarnowskie" ${ }^{58}$.

Odtąd sprawy potoczyły się bardzo szybko. W dniu 13 III $1786 \mathrm{r}$. papież Pius VI bullą In beati Petri erygował diecezję tarnowską, a w dniu 3. IV t. r. bullą Apostolatus officium prekonizował ks. F. A. Janowskiego na biskupa tarnowskiego, o czym w bulli Gratiae divinae praemium z tegoż dnia powiadomił ces. Józefa II. Tego samego dnia zostały wysłane bulle Ad cumulum Tuae do metropolity lwowskiego F. Kickiego; którego jurysdykcji metropolitalnej miała podlegać nowa diecezja, oraz Hodie nos do kleru i wiernych diecezji tarnowskiej. W trźy dni później tenże papież w bulli Cum nos pridem (6 IV 1786) zgodził się, by nominat mógł przyjąc konsekrację biskupią z rąk jednego biskupa i-dwóch opatów ${ }^{59}$. W dniu 16 VI 1786 r. bulle papieskie otrzymały placetum regium ${ }^{60}$.

Kiedy wszystkie sprawy o charakterze prawnym były załatwione, biskup nominat F. A. Janowski otrzymał w dniu 13 VIII 1786 r. sakrę biskupią w archikatedrze lwowskiej z rąk metropolity lwowskiego ob-

${ }_{56}$ Allgemeines Verwaltlungsarchiv. Wien. Alte Kultus Akten. Fasc. 144 Tarnow. Nr 519 ex Decembri 1785: Wniosek Nadwornej Komsiji Duchownej do ces.' Józèfa: II -14 XII 1785 .

57 Tamże, nr 519 ex Decembri 1785: Decyzja ces. Józefa II - 23 XII 1785.

2. 58 Tamże, nr 476 ex Februario 1786: Kard. Herzan do Nadwornej Kancèlirli w Wiedniu - 26 I 1786; Wniosek Nadwornej Komisji Duchownej do ces. Józefa-II 10 II 1786; Ces. Józef II do pap. Piusa.VI - 22 II 1786; Dziesięé dokumentów, 365366 (12n 10$)$

${ }_{59}$ Tamże. Nr 371 ex Majo 1786 (Kopie bull papieskich); Nr 376 ex Majo 1786. Bp Janowski do pap. Piusa VI - bez daty; Hierarchia catholica, t. 6, 393. ..h. 60 Tarhże: Nr. 564 ex Septembri 1786: Gub. Autersperg do Kancelarii Nadwornej w Wiedniu - 16 VI 1786. 
rządku łacińskiego F. Kickiego w asyście arcybiskupa lwowskiego obrządku ormiańskiego Jakuba Tumanowicza i biskupa przemyskiego ôbrządku greckokatolickiego Piotra Bielańskiego. W dniu 24 IX 1786 r. biskup Janowski odbył uroczysty ingres do katedry tarnowskiej. Rządy swoje w diecezji sprawował do śmierci (4 I 1801). Dnia 8 I 1801 r. kapituła katedralna $\mathrm{w}$ Tarnowie wybrała na administratora diecezji prepozyta kapitulnego, ks. Wojciecha z Bożej Woli Górskiego, który w tym charakterze zarządzał diecezją aż do jej kasaty w dniu 13 VI 1805 r. Faktyczne rządy ks. Górskiego jako administratora diecezji trwały do 6 I 1808 r., kiedy to jakso biskup nominat kielecki opuścił Tarnów i przeniósł się do Kielc, a zarząd podzielonej diecezji przejęli biskup krakowski A. R. Gawroński i biskup przemyski A. Gołaszewski ${ }^{61}$. Tak zakończył się pierwszy okres dziejów diecezji i obsady biskupstwa w Tarnowie.

W przypisach zastosowano następujące skróty wydawnictw ciągłych: ABMK - Archiwa Biblioteki i Muzea Kościelne; Hierarchia catholica - R. Ritzler, P. Sefrin, Hierarchia catholica medii et recentioris aevi, t. 6 (1730-1799), Patavii 1958; PSB - Polski Słownik Biograficzny,

DE NOMINATIONE PRAESENTATIONEQUE EPISCOPORUM TARNOVIENSIUM ANNIS $1783-1807$

Sum marium

Eam partem meridionalem dioecesis Cracoviensis, quam anno 1772 a Polonia avulsam et ab Austriaco exercitu occupatam, territorium novae dioesesis Tarnoviensis constituere, ab omnibus optime scitur. Ut etiam omnes nexus tam ecclesiastici quam etiam politici huius galicianae partis dioecesis cum Cracovia et Polonia rescindantur, gubernium Austriacum his in oris vicariatum apostolicum erigere et in vicarium apostolicum unum praelatorum Bohemiae nominare intenderet, negotiumque in hac re Romae institueret (1774). Conatus isti minime ad finem felicem adducti, causam novae resolutionis dederunt, idque ut nominatio coadiutoris cum futura successione tantum pro parte galicianae dioecesis perficeretur. Sed etiam suggestio illa, ex toto iuri canonico contraria, finem suum obtinere minime potuit.

Interea die 27 IX 1777 episcopus Cracoviensis Ignatius Caietanus Soltyk in parte galiciana suae dioecesis officialatum generalem in Zakrzówek prope Cracoviam ipsam erexit, atque auxiliarem surum Cracoviensem episcopum Franciscum Potkański hoc munere decoravit. Idem ordinarius Cracoviensis initio anni 1781 sedem vicariatus e Zakrzówek Tarnoviam transtulit, munusque officialis praeposito templi collegialis in Wojnicz Joanni Duwall commissit.

Anno 1783 imperator Austriae Josephus hoc nomine II, sine scitu et venia Sedis Apostolicae, novam dioecesim Tarnoviensem fundavit, atque officialem Tar-

${ }^{61}$ B. Kumor, Dzieje polityczno-geograficzne diecezji, 47 n., 61 nn.; Tenże, Granice, 292. 
noviensem Joannem Durwall in primum episcopum huius dioesesis nominavit. Negotiatione his in rebus Romae finita, Apostolica Sedes ius nominandi et praesentandi futuros episcopos Tarnovienses Sacrae Caesarae et Apostolicae Majestati concedit (1785). Joanne Duwall nominato e vivis ante praeconisationem erepto, Caesarea Majestas in novum episcopum Tarnoviensem abbatem Tymiecensem Florianum Amandum Janowski et elegit et nominavit (1785). 